\title{
Enron of Saudi Arabia: Corporate Accounting and Auditing Failures
}

\author{
Ayman Mohamed Zerban \\ Accounting Department, College of Business Administration, University of Business and Technology, Jeddah, Saudi Arabia \\ Email: ayman@ubt.edu.sa
}

How to cite this paper: Zerban, A.M. (2018) Corporate Governance, Accounting and Auditing Failures, Saudi Arabia. Open Journal of Accounting, 7, 1-18. https://doi.org/10.4236/ojacct.2018.71001

Received: October 10, 2017

Accepted: November 17, 2017

Published: November 20, 2017

Copyright $\odot 2018$ by author and Scientific Research Publishing Inc. This work is licensed under the Creative Commons Attribution International License (CC BY 4.0).

http://creativecommons.org/licenses/by/4.0/

\begin{abstract}
Accounting and auditing failures are still a hot topic despite strong efforts for efficient corporate governance. The motives and attitudes behind decisions and events leading to Enron's eventual downfall appear to be simple. It is individual and collective greed born in an atmosphere of market loose of regulation. The financial results of the company were too good to be true and no sound was heard to criticize the company albeit very few opinions. It was a network to deceive stakeholders. Saudi Arabia government has sought to change its oil-based economy into a modern diversified economy with a more trend towards privatization consistent with 2030 vision "a vibrant society, a thriving economy and an ambitious nation" and in this situation an effective, transparent, accountable, enabling and high-performing government and corporations are an essential pillar for success in order to advance economy including stock market. Corporate governance is intended to increase accountability of corporations and to avoid problems before they occur. An accounting scandal at one of Saudi Arabia's largest telecommunications companies is posing pressure on regulators, as Saudi Arabia moves to open up the Arab world's largest stock market to foreign investors. The Capital Market Regulator in Saudi Arabia banned Deloitte's firm (Bakr Abulkhair \& Co.) from auditing public companies as of June $1^{\text {st }}, 2015$, on account of its work for the targeted loss-making company MMG (Mohammad Al Mojil Group). Another scandal in Saudi Arabia is Etihad Etisalat, known as (Mobily), as company's audit committee pointed in their perspective to accounting errors that decreased about $\$ 380$ million in previous profits. The aim of this research is to explore what went wrong and the violations of corporate governance rules by highlighting corporate accounting and auditing scandals in MMG (Mohammad Al Mojil Group) and Etihad Etisalat, known as (Mobily). Although what happened at Enron is very well known worldwide, the corporate accounting and auditing failures in the case of Saudi Arabia is unprecedented territory of research.
\end{abstract}




\section{Keywords}

Corporate Governance, Accounting and Auditing Failures, Saudi Arabia

\section{Introduction}

Most studies about corporate failure are based on companies in western economics with well-established and solid financial infrastructure and despite this still misleading financial numbers are presented and stakeholders are left duped. It seems that the problem of corporate accounting and auditing fraud is increasing in intense and allover regions from Satyam (India) to Toshiba (Japan) just mentioning a few. Fraud can be seen as a deception or misrepresentation of financial numbers with and intention to make benefits. It involves different levels in organizations.

This study is different as it is going to explore corporate accounting and auditing scandals in other contexts than western economics which is Saudi Arabia. MMG (Mohammad Al Mojil Group) and Etihad Etisalat, known as (Mobily), are the concern of this study with their auditors and financial advisors. The collapses of Enron, WorldCom, Parmalat at the beginnings of the $21^{\text {st }}$ century and recently Volkswagen and Toshiba scandals of 2015 shed lights about the applications of corporate governance rules and whether accounting is a tool for decision making that help investors or it is enhancing greed of management by presenting misleading financial numbers. Many participants contributed to financial scandals, it is not a responsibility of one party only. Accountants, auditors, management, regulators and banks are all contributed to the recipe of failure. It was a synergetic corruption where every party plays his role and enjoys the benefits. The concern here is to highlight what went wrong as well as lessons to be learned in Saudi Arabia in order to prevent such crises from happening in the future.

In today's world, business is connected. The slow-down in economic development in developed countries can lead the global economy to recession. The effects of misleading financial information are tremendous. Fraudulent financial information can impact users of financial information to make wrong financial decisions. Mathisen and Foley (2006: p. 5) state [1]:

The devastating results of Enron improprieties affected employees' jobs, retirement funds as well as complete destruction of share values. Subsequently, the former Treasurer, Ben Glisan, pled guilty to criminal conspiracy and for which he received a prison sentence (Enron, 2006). Mr. Fastow, CFO, also pled guild to "fraud, money-laundering and conspiracy" for which he received a 10 year prison sentence and was forced to pay \$24 million. Roughly twenty other Enron executives have been charged with felonies including Kenneth Lay, former CEO.

Mangers sometimes try to get maximum benefits by presenting false information 
related to the financial performance and financial position of companies (ISA, 2011) [2]. Corporate financial scandals have negative impact on the value of organizations that are committing fraud. The drop of Enron Corporation's value from 70 billion dollars to nearly zero is an evident example. In Saudi Arabia, MMG (Mohammad Al Mojil Group) stock was offered in stock market at 20 dollars and few years later it is 30 cent while Etihad Etisalat, known as (Mobily) was nearly 20 dollars in 2012 and it reaches nearly 5.3 dollars on $12^{\text {th }}$ January 2017 (Figure 1).

According to the Association of Certified Fraud Examiners (2014) [3], occupational fraud can be classified into three categories: Firstly, asset misappropriations which are related to misuse of organization's resources; Secondly, corruption schemes by employee's to get benefits; Finally, financial statement fraud schemes are those involving the intentional misstatement or omission of material information in the organization's financial reports. Common methods of fraudulent financial statement manipulation include recording revenues which are not existed, decreasing liabilities or expenses and mispresenting reported assets. It states (p. 12, emphasis added) [3]:

Of the three primary categories of occupational fraud, asset misappropriation is by far the most common, occurring in more than $85 \%$ of cases analyzed for this Report; however, it is also typically the least costly of the three types, causing a median loss of $\$ 130,000$. In contrast, financial statement fraud occurs much less frequently, accounting for $9 \%$ of the cases in our latest survey, but it causes the greatest financial impact of the three categories by far, with a median loss of $\$ 1$ million. Corruption tends to fall in the middle in terms of both frequency and median loss.

Kassem and Higson (2012) [4] criticize Fraud Triangle Theory (pressure, opportunity, and rationalization) and argued for its extension to include all factors that help to understand why fraud occurs such as motivation, opportunity,

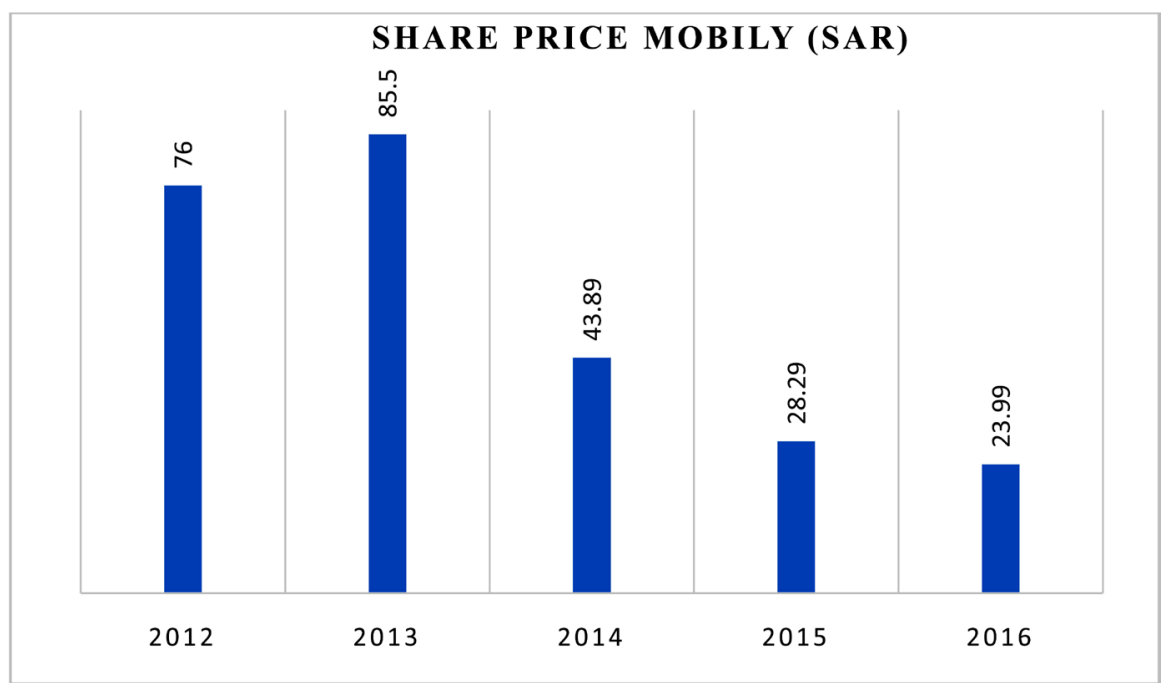

Figure 1. Stock Chart for Mobily Share price 2012-2016. 
integrity, and fraudster's capabilities. This model should be called "the New Fraud Triangle Model". External auditors will consider all the necessary factors contributing to the occurrence of fraud. In the same vein, Wolfe and Hermanson (2004) [5] argued for Fraud Diamond Theory in which capabilities of the person committing fraud is very important. He/she capabilities in dealing with stress resulted from committing bad acts is vital in the process. A successful fraudster is an individual who has personality of convincing others to his way and line of thinking the he/she "must look at the auditors, investors, and others right in the eye and convincingly tell them lies. Thus, the fraudster should also possess the skill to keep track of the lies, so that the overall story remains consistent" (Abdullahi and Mansor, 2015: p. 40) [6]. The increasing intense of fraud cases, corporation began to hire forensic accountants to prevent and reduce the issues related to fraud.

The Fraud Theory provides the methodological framework for this study by highlighting real corporate accounting and auditing scandals in MMG (Mohammad Al Mojil Group) and Etihad Etisalat, known as (Mobily) in Saudi Arabia and describe what went wrong in accordance to violations to corporate governance framework. The paper proceeds as follows. Section two is going to explain corporate governance as a cornerstone in protecting stakeholders. Thirdly, accounting and auditing failure in developed countries is going to be highlighted. Fourthly, corporate accounting and auditing failure in some Saudi Arabia corporations is going to be explained. Finally, fifth section is a conclusion for the paper.

\section{Corporate Governance as a Cornerstone in Protecting Stakeholders}

The topic of corporate governance has received great attention lately due to collapse of popular companies and the question that raises in the media and by academic community is what about less notable firms? Corporate governance is a mechanism through which shareholders are assured that managers will act in their interests. Efficient corporate governance can help to prevent corporate scandals as well as support trust between companies and societies. It enhances image and reputation of a company and makes it more attractive to stakeholders. For investors one of the most important aspects when making an investment decision is level of implementation of corporate governance principles (public disclosure of information, protection of shareholder rights, equal treatment of shareholders) and profitability, which ensures adequate return on their investment (Todorovic, 2013) [7]. The relation between corporate governance and market value of Korean public companies is strong. Black et al., (2003) [8] examined 531 of the 560 companies listed on the Korea Stock Exchange and found a positive correlation between corporate governance index and firm value. In Indonesia, Haryono and Paminto (2015) [9], examined the relation between corporate governance and financial performance and the impact on idiosyncratic 
and systematic risk of 44 mining sector companies listed in the Indonesia Stock Exchange in the year period of 2009-2014. Their results clarified that corporate governance has positive significant effect to the financial performance and negative significant effect to the firm risk.

Accounting information is a cornerstone in the functioning of any economy. It should have certain qualities such as objectivity, reliability, relevance, completeness and accuracy. Corporate governance as a framework provides the foundations in managing companies and its relations with stakeholders. It has the potential to minimize conflicting interests between managers and shareholders and improves quality of financial reporting aiming to enhance accountability. Thus, internal and external governance mechanisms are designed to reduce the agency cost. The effectiveness of a board as a corporate governance mechanism depends on its composition, size and role. When the board of directors is independent, it improves companies' financial performance (Ho et al., 2012) [10]. Klai and Omri (2011) [11] conducted a study to assess effectiveness of corporate governance on financial information quality for a sample of Tunisian non-financial companies listed on the Tunis Stock Exchange during the period 1997-2007. Their study clarifies that Tunisian firms are characterized by the lack of the board independence and the high level of ownership concentration which involves a poor quality of financial disclosure. Many companies are characterized by CEO duality. In the same vein in other context which is China, Firth et al., (2007) [12] results find that companies with more independent directors that separate the roles of chairman and executive director have greater earnings informativeness. The board's greater independence is an issue accompanied a higher quality of accounting information.

Al-Twaijry et al. (2002) [13] argued through interviews with thirty three nonrandom sample who are academics, external and internal auditors that the relations between audit committee's members and executives of companies hinder internal control process but expertise is important for effectiveness of corporate governance. Alzeban (2015) [14] examined the effectiveness of audit committees in Saudi Arabia and concluded that a positive correlation exists between level of expertise of members in audit committee including professional expertise and effectiveness of internal control. Companies should hire members in audit committees who have audit and professional expertise.

Managers commit accounting and auditing frauds to hide and window dress true business performance, to preserve personal status, control and to maintain personal income and wealth and in some opinions to preserve their ego. Accountants present financial statements related to their area of responsibility to hide poor performance or to earn bonuses. Organizations try to obtain loans, or managers try to inflate stock prices they plan to sell in a "pump-and-dump" scheme (Kassem and Higson, 2012) [4]. Bhasin (2013) [15] highlighted fraud committed by the founders of Satyam (India) in 2009 which shows the weakness of corporate governance in emerging economics. Satyam Computer Services 
Limited was developed as a pioneer in the Indian outsourced IT-services industry. The company was formed in 1987 in Hyderabad (India). It grew from just few people to an icon everybody wants to belong to. It won numerous awards for innovation, governance, and corporate accountability. Ironically, Satyam in the ancient Indian means truth. The company demonstrated an annual compound growth rate of $35 \%$ over that period from 2003-2008. Earnings per share similarly grew, from $\$ 0.12$ to $\$ 0.62$, at a compound annual growth rate of $40 \%$. He states (p. 30) [15]:

On January 7, 2009, Mr. Raju disclosed in a letter to Satyam Computers Limited Board of Directors that "he had been manipulating the company's accounting numbers for years". Mr. Raju claimed that he overstated assets on Satyam's balance sheet by $\$ 1.47$ billion. Nearly $\$ 1.04$ billion in bank loans and cash that the company claimed to own was non-existent. Satyam also underreported liabilities on its balance sheet. Satyam overstated income nearly every quarter over the course of several years in order to meet analyst expectations ... The company's global head of internal audit created fake customer identities and generate fake invoices against their names to inflate revenue.

Ho et al., (2012) [10] examine the effect of changes in corporate governance systems on the financial ratio disclosure practices in Malaysian firms. They found a statistically significant rise in the overall extent of financial ratio disclosure between 2001 and 2006. Alves (2011) [16], conducted a study on a sample of Portuguese companies for the years 2002-2007 and concluded that the ability of managers to manage an organization's reported results is limited by the effectiveness of internal controls, including that of boards. Boards are responsible for monitoring the quality of information contained in financial statements and thus controlling the behavior of managers to ensure that their actions are aligned with the interests of stakeholders. She provides evidence that both managerial ownership and ownership concentration reduce management flexibility in generating abnormal accounting accruals. Her study suggests that despite differences in institutional environments, ownership structure is important to ensure highquality financial reporting. Also there is less earnings management when operating cash flows are high and that there is more earnings management when political costs, leverage and board size are high.

\section{Accounting and Auditing Failure in Developed Countries}

Fraudulent financial statement became a habit where every year the public witnessed spectacular business failures. The lost in confidence and trust undermined auditor's credibility and the public accuse accounting and auditing profession. So coupling problems in measuring and communication together with fraudulent financial statement, we will have a recipe of complete disaster. As pointed by Adkins (2009: p. 1) [17]: 
Financial statements manipulation is an ongoing problem in corporate America. Although the Securities and Exchange Commission (SEC) has taken many steps to mitigate this type of corporate malfeasance, the structure of management incentives, the enormous latitude afforded by the Generally Accepted Accounting Principles (GAAP) and the ever-present conflict of interest between the independent auditor and the corporate client continuous to provide the perfect environment for such activity.

One of the most prominent examples of corporate failure is Enron Corporation. Enron Company started in 1985 through the acquisition of InterNorth and Houston Natural Gas companies, which made Enron the leading natural gas pipeline system in the United States. All of a sudden SEC began to be suspicious about Enron valuations of assets and improper accounting practices. Arthur Anderson who was Enron's regular auditor became creative and innovative in dealing with financial numbers and instead of making sure they are true and fair. The company's managers were questioned for presenting misleading accounting information enhanced by their greed. Enron's CFO, Andrew Fastow was at the pivotal point of what appeared to be "off balance sheet liabilities". The results were complete devastation to share value, thousands of employees lost their jobs and retirement benefits and one of the big five accounting and auditing firms vanish in a very short time. Financial markets effected, cost of financing increased and accounting and auditing profession is under fire (Thomas, 2002) [18]. The use of Mark-to-Market accounting or fair value accounting in which companies can evaluate their trading securities and book unrealized gains or losses in the income. Although the technique may works well in trading securities because of the presence of quoted price, in energy and gas industry which is long term contracts the valuation is in doubt. Companies rely in valuation to their best judgment. In order for the company to glory their profits estimates and to please Wall Street fueled by senior manager's greed, the financial numbers instead of being true and fair became the imagination of managers. Instead of focusing on gas operation the company became a speculator with magical accounting tricks. Thanks to the rule of debits and credits. Enron's managers created many special purpose entities to hide debts and to keep leverage ratios normal to get the confidence of credit rating agencies and investors. Enron's Executives were working against the interests of shareholders. Enron favors "mark-to-market" for booking the value of contracts extending out into the future and calculates their value based on current market prices and hence increase profits and please Wall Street. Managers favor their self-interest instead of creating wealth to shareholders (L'Huillier, 2014) [19]. Edelman and Nicholson (2011: p. 3) state [20]:

With debt still visible, financial analysis' ratings for Enron were lower than the company desired. Andy Fastow, Enron's CFO, led the company in the use of special purpose entities (SPEs) to increase capital and improve Enron's rating. SPEs are partnerships with an outside party that allow the 
company to increase its ROA and leverage without required reporting of debt on the company's financial statements. Thus, Fastow was able to hide Enron's debt through approximately 500 SPEs.

On the other side of the Atlantic, Parmalat (Italy) is a prominent example for accounting and auditing fraud. In 2002 Parmalat was the listed holding of a multinational food group made up of more than 200 companies spread around 50 countries. The group was a world leader in the markets of milk, dairy products and beverages. It operated 139 industrial plants and more than 36,000 employees with a consolidated sales revenues 7.6 billion Euros. The company was accumulating debts and markets became suspicious about their transparency and ability to meet debt obligations. It did not comply with Italian Corporate Governance Standards of best practice and it was a "false accounting story" (Melis, 2005: p. 478) [21]. Investigators argued that Parmalat had only one profitable year from 1990 to 2002 despite the company showing profits in their financial statements each year (Roberts et al., 2004: p. 219) [22]. The CEO/Chairman duality hinder corporate governance effectiveness and concentrates power. Deloitte when reviewing financial statements of the company said that they "could not give a "fairness opinion" of the true value of Parmalat's open ended mutual fund Epicurum" (Ferrarini and Giudici, 2005: p. 11) [10]. Duval (2016: p. 1) [23] pointed to the acts of big four companies by stating:

In 2010, the Public Company Accounting Oversight Board (PCAOB), the US regulator of auditing professions, denounced an increase in errors of the Big Four firms (KPMG, E\&Y, PwC and Deloitte) operating in the United States. Deloitte blithely achieved the inconceivable with $45 \%$ of copies for review, against $22 \%$ in 2009 , followed closely by $\mathrm{PwC}$ with $39 \%$ of audits being unsatisfactory in 2010 (against 12\% in 2009). Despite this, undaunted, the four multinationals in consulting and auditing, continued on their way, disdaining the scandals that marked their paths, their eyes riveted on austere accounting statistics and other profitability indicators at the antithesis of sustainable well-being ...

Parmalat hide losses, overstate assets especially cash and understate liabilities. It recorded non-existent redemption of bonds. The internal control committee was composed of three members. Two of these members also was members in the executive committee and one was the company chief financial officer. Thus, non-executive directors did not represent the majority of the committee and has no active role. It could be described as having (Ferrarini and Giudici, 2005: p. 12) $[24]:$

Questionable accounting and accountants, poor underlying performance, political connections, a dominating shareholder, complex corporate structures and operational mystery. In contrast with other bankrupt firms, however, Parmalat's governance structures did not appear to be well-designed or state-of-the-art. 
In Japan, on July 21, 2015, Toshiba's CEO resigned after admitting that the company overstates its profits by approximately $\$ 4.1$ billion USD between (2012-2015). Despite having four independent directors in the board which is $25 \%$ from board members, the misrepresentation of financial statements occurred. Audit committee members include two participants who lack accounting or auditing professional backgrounds and were diplomates (Chikatsu, 2015) [25]. Accounting method called "percentage-of-completion Method", which is commonly used in long-term projects played a role in overstating profits. The accountants lower expenses in early year's periods of future projects. The targeted profit levels that cannot be achieved by employees creates a pressure leads to fraud. Revenues were declining and demand fell for products, thus pressure built up. Internal control system was weak and the culture in the company was a leader follower where managers follow CEO without questioning (Khondaker and Marc, 2016) [26]. Ernst \& Young (EY) ShinNihon, a leading audit company was the auditor of Toshiba and they "did not make any note of the anomalies" (Ibid: p. 92) [26]. The misrepresentation continued for seven years until Securities and Exchange Surveillance Commission investigated Toshiba's accounting practices and discovered the misconduct. They State (Ibid: p. 91) [26]:

The nexus of the problem is that managers exercise their own discretion on whether to recognize these changes in values. Toshiba's managers decided to selectively adjust these changes in value to fraudulently over-report their profits. The discretion given to managers, with the acquiescence of auditors, means that there is a real danger of overstated profits and sales and corresponding understatements of expenses as well as under provisioning for soured contracts and negative adjustments to goodwill.

However, Toshiba scandal is not a single incident in Japan in violating corporate governance principles, for example in 2004 Nikko Cordial Corp. was inflating their profits and providing misleading information. The company issued 50 billion yen in corporate bonds in November 2005, and its fiscal 2004 business report was used to give false explanations about the brokerage's financial condition to prospective investors.

Next section is going explore corporate accounting and auditing scandals in MMG (Mohammad Al Mojil Group) and Etihad Etisalat, known as (Mobily) in Saudi Arabia and violations to corporate governance framework and how this crises effect society.

\section{Mohammad Al Mojil Group (MMG) and Etihad Etisalat (Mobily) in Saudi Arabia}

The interest in corporate governance has gained prominence in Gulf area and worldwide. Baydoun et al. (2013) [27] compare the dimensions of corporate governance in five countries which are Kuwait, Bahrain, the United Arab Emirates, Qatar and Oman. Saudi Arabia were excluded due to unavailability of comparable data. They examine shareholders rights and obligations; internal enterprise 
processes, including management structures, reward systems; and transparency. According to their survey the highest country in corporate governance measurement scale is Oman (first country in the region to issue corporate governance standards in 2002) while the lowest country among the five countries is Qatar.

Mohammad Al-Mojil Group (MMG) started his company in Dammam city in the Eastern Region of Saudi Arabia on 1954 and was registered as a sole proprietorship on June $24^{\text {th }}$. They provide all construction activities and inspection services required for engineering and manufacturing projects. MMG offers certified calibration facilities. MMG is a leading contractor in the oil, gas and petrochemical sector. On $10^{\text {th }}$ November 2007 , MMG converted into a joint stock company in accordance with the resolution of the Ministry of Commerce and Industry in order for the company to offer its shares in the stock market in initial public offering (IPO). Revenues of the company grew from SAR 466 million in 2005 to SAR 1995 million in 2007 before the IPO with an increase 328\% in just two years. During 2007, Sheikh Mohammad Hamad Al Mojil resolved to transfer the legal structure of Mohammad Al Mojil Company from a sole proprietorship to a Saudi limited liability company and increase the Company's share capital from SAR 4.4 million to SAR one billion from shareholders' current account and retained earnings. The "value of properties were determined through appraisals furnished by independent real estate agents" (MMG, 2008: p. 58) [28]. Property and equipment were increased from SAR 316 Million to SAR 1044 Million from 2005 to 2007 before the IPO with 223 percent increase. According to financial reports issued accompanying prospects for the IPO, the company argued that financial statements were prepared in confirmatory with generally accepted accounting principles and the use of estimates in reporting assets and liabilities. The Accountant's report states "estimates are based on management's best knowledge of current event and actions, actual results ultimately may differ from those estimates" (Ibid, 2008: p. 54) [28]. Deloitte (Bakr Abulkhair \& Co) still issued unqualified report stating that financial statements present fairly in all material aspects the financial position of the company.

In 2008, MMG became a publicly traded company and the Founder Mohammad Al-Mojil took the decision to sell a 30\% stake in the contractor through IPO. The company paid in capital was SAR one billion divided into 100 million shares with par value of SAR 10 per share and an issuing price SAR 70. The financial advisor was HSBC and the company was reevaluated by SAR seven billion and its financial statements were approved by Deloitte. The founding shareholders collectively own $70 \%$ of the share capital post IPO in May 2008. The share paid in capital in excess of par value SAR one billion and eight hundred million based on the $30 \%$ offered to the public. Three entities share the underwrite of stocks were made by HSBC Saudi Arabia Limited for 15,000,000 shares, National commercial Bank for 7,500,000 shares and Riyadh Capital for 7,500,000 shares. The following chart clarifies that the company was making profits in the 


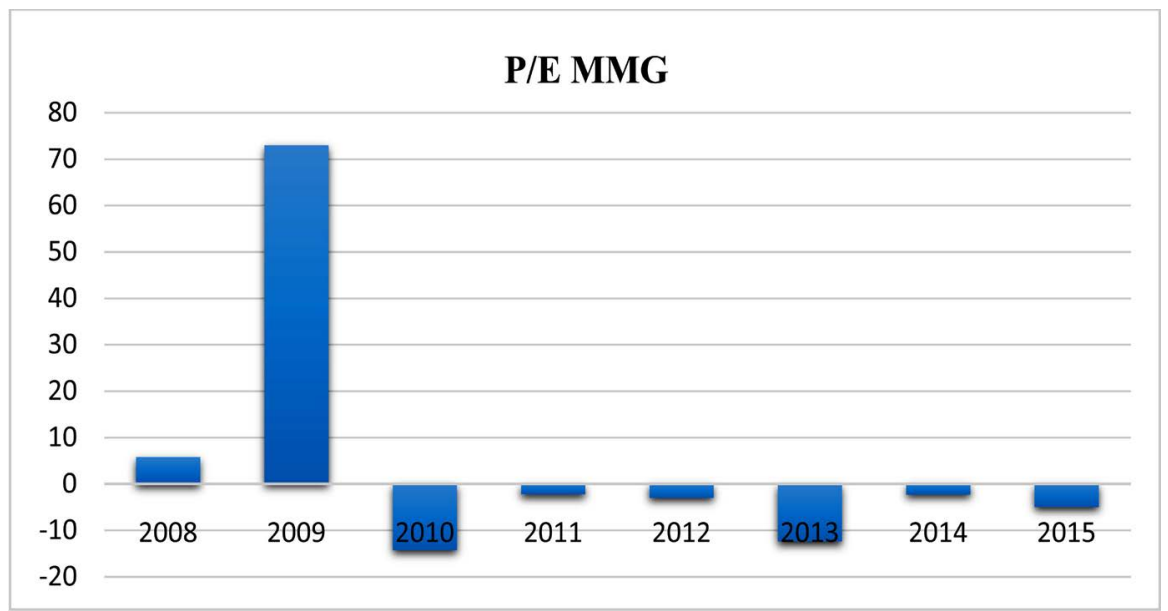

Figure 2. P/E Ratio Mohammad Al Mojil Group (MMG) (Arab Stock Market Analysis).

year following the IPO then it starts making losses from 2010 till 2015. The P/E ratio of MMG witnessed a sharp decline from 2009 till 2015 (Figure 2).

As the firm incurred significant losses in 2013, Capital Market Authority (CMA, hereafter) suspended trading of MMG shares on the Saudi Stock Exchange, Tadawul. Later that year, in conjunction with financial consultancy Protiviti Member Firm (Middle East) Ltd, the Saudi regulator began to investigate MMG's operations and financial reporting for the period 2005 to 2012. Once the investigation was complete, the CMA instructed Protiviti to document its findings in a report, which was delivered on 30 June, 2013. The investigation of the CMA continues its course with former leaders of Deloitte implicated for breach of the rules on the losses accumulated during the certification of the accounts of the Mohammad Al-Mojil Group (MMG), whose shares have been suspended since July 2013 for the presence of huge amounts of debts. KPMG which was appointed as external auditor for MMG group issued a disclaimer opinion on the consolidated financial statements of the company after losses exceed $75 \%$ of its capital and a negative working capital SAR 1.5 billion and made doubts that the company is going concern. According to CMA regulation for public listed companies, shareholders have to vote for the continuity of the company when losses exceed 75\% of capital and the decision was to continue (MMG, 2012) [28]. Actually Sheikh Mohammad Hamad Al Mojil and family members owns more than $50 \%$ of the company and the vote was a big failure. CMA Board has issued its resolution Number (4-48-2013) Dated 18/11/2013 for listed Companies with Accumulated Losses reaching \%50 or more of its Capital. These instructions should be effective $1 / 7 / 2014$. The purpose of the instructions and procedures is to regulate the mechanism for dealing with a company whose shares are listed in the stock market when its accumulated losses reach $50 \%$ or more of its capital (Saudi Stock Exchange, 2013) [29]. In my opinion it is too long to wait for nearly seven months to deal with the situation and already stakeholders are duped and losing their fortune. Also companies are allowed to trade over the counter for two full financial years when accumulated losses reach $100 \%$ or more. The Equity 


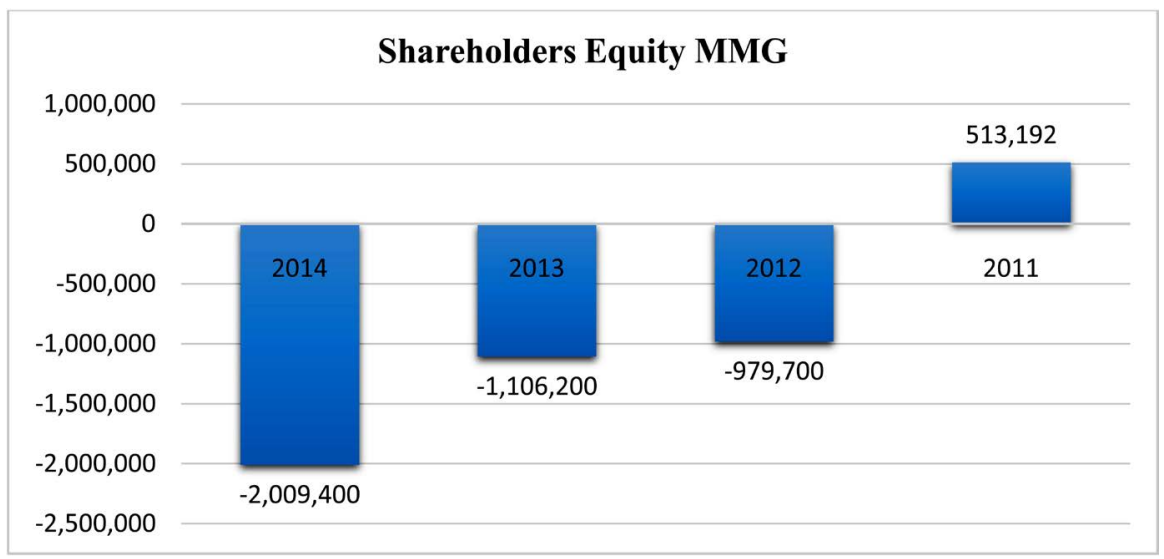

Figure 3. Shareholders Equity MMG 2011-2014.

of MMG reaches negative 2 billion Saudi riyals by 2014 (Figure 3).

MMG recognized revenues according to percentage of completion method. The company audit report prepared by KPMG admitted that its losses should increase in 2011 due to error of estimation by SAR 150 million to reach SAR 1.1247 billion. Unbilled revenues has to be restated and a decrease in assets due to error in revenue recognition. Write off accounts receivable for 2011 by SAR 289 million which represents almost $85.8 \%$ of the balance of receivables. Impairment losses due to re-measurement of property plant and equipment by SAR 135.1 million. The company violates its long term financing covenant with local commercial bank amounted SAR 169.8 million. KPMG cast doubts about the uncertainties surrounding the company and its ability to continue operation (MMG, 2012) [28].

The cumulative loss of MMG at the end of October 2014 amounted to 2.79 billion riyals, equivalent to $223 \%$ of its capital, according to the current stock exchange of November 13, 2014 (Duval, 2016) (MMG, 2012) [28]. Initial reports suggested that the Committee for the Resolution of Securities Disputes had banned Deloitte from providing auditing services in the kingdom for a period of two years for companies listed in Saudi Stock Market. The Capital Market Authority on a letter dated $11^{\text {th }}$ of November 2014 to listed companies in Saudi Stock Market confirmed the "banning of Deloitte Saudi Arabia and two of the partners from legal accounting duties to any company listed or planned to be listed from $1^{\text {st }}$ of June, 2015 until the MMG case is settled" (Capital Market Authority, 2014: p. 1) [30]. On 18 November, 2014, the CMA issued a charge sheet containing allegations against Mohammad Al-Mojil, his son Adel Al-Mojil, and others, in relation to MMG's IPO and CMA accused the company for guilty of manipulation and fraud relating to the MMG's initial public share offer in 2008. Mohammad and Adel Al-Mojil were each sentenced to five years' imprisonment for misrepresenting MMG's value. A third unnamed executive from the contractor received a three-year prison sentence, according to news agency, Reuters. Deloitte \& Touche Bakr Abulkhair \& Co, the Saudi Arabia arm of Deloitte Touche Tohmatsu Ltd, also came under fire, owing to its historic work with 
MMG (MMG, 2012) [28].

According to Jones and Patrick (2015) [31], CMA in September 2015 suspended the HSBC unit (SABB, Saudi Arabia) from conducting some assetmanagement activities and is investigating whether it inflated the valuation of a construction firm's listing in 2008. SABB in Saudi Arabia began "to restructure its board and governance committees, and has hired new management at the division, according to Majed Najm, Chief Executive of HSBC Saudi Arabia. "The result of the reforms is a stronger, better managed business," (Ibid: p. 1) [32].

On 16 June, 2016, the Committee for the Resolution of Securities Disputes part of Saudi Arabia's Capital Market Authority (CMA) penalized the local arm of US-headquartered Deloitte Touche Tohmatsu for its involvement in the case (Everington, 2016) [32]. The committee pointed that there is a misrepresenting in MMG's value. MMG was ordered to pay SAR 1.6 billion for illegal profits and imposed a separate fine of 2.7 million riyals. On $19^{\text {th }}$ of June 2016 the board announces their resignation with a need to elect new board to run the company. According to Argaam after resignation of old board the founder Mohammed Al Mojil, didn't show up for a meeting to elect five board members and shareholders' spokesman Shakhbout Al-Dosari who were appointed as CEO for the company in 2016 and resigned in less than two months asked for the need to (2016: p. 1, emphasis added) [32]:

Identify the person responsible for misleading investors, in the latest in the verbal war between the company and its shareholders...... Shareholders are in trouble situation because of the pre-IPO release approved by MMG, he added. Investors who bought stocks in the market didn't make decision based on rumors, but based on misleading financial information from the company. "We, as shareholders, had been deceived by the IPO's subscribers and traders until the company was suspended from trading".

Another accounting and auditing failure with tremendous impact on investors is Mobily Saudi Arabia's which is second largest telecommunications operator. The case Etihad Etisalat (Mobily) in Saudi Arabia is equivalent to what happened in MMG but the difference is that it is still operating and listed in Saudi Stock Exchange. It is a joint stock company started operation in 2005 and from 2006 the company began to show profits. Although the company belongs to telecommunication industry which requires huge investments and intensive capital and in its financial statement profits are increasing gradually after inception. During 2008 its profits increased 52\% compared to 2007. Mobily stock is usually outperforming the Saudi Stock Market during the last years of the first decade in $21^{\text {st }}$ century and through first half of second decade. In 2015 annual report of Mobily states that "Mobily faced difficulty related to accounting issue, which led to the restatement of its financial statements" (Annual Report Mobily, 2015: p. 14) [33]. Company in 2014 began to have negative working capital by nearly fifteen billion SAR and huge losses with mountains of debts. It "breached a certain financial covenant under its long-term financing facilities" (Ibid, 2015: p. 48) 
[33]. The return on assets in 2015 was $-2.58 \%$ and return on equity $-7.03 \%$. The EPS of the company decreased dramatically after restating financial statements (Ibid, 2015) [33]. Mobily fired Khalid al-Kaf as chief executive, and select his deputy, in temporary charge while the company's audit committee pointed to accounting errors that decreased about $\$ 380 \mathrm{~m}$ in previous profits. The capital markets authority in Saudi Arabia opened up an investigation into the accounting errors to determine whether the company violated the stock market's rules and announced more than one person was suspected of violating regulations on insider trading. Martin and Almashabi (2015: p. 1) state [34]:

Abdulaziz Alsaghyir Commercial Investment, of which Alsaghyir is founder and chairman, last year sold about two-thirds of its stake in Mobily, Alsaghyir resigned as chairman due to health reasons .... Mobily has lost about $\$ 9$ billion of its market value since the accounting errors were discovered four months ago. The Capital Market Authority is probing the company for suspected violations of rules related to the disclosure of financial information, market manipulation and insider trading. Its Chief Executive Officer Khalid Al Kaf left the company last month.

Mobily reported a sharp decline in profits in the third quarter 2014 and restated earnings through 2013. Restatement of income from a loyalty program since 2013 amounted to SAR 1.42 billion. Watfa (2015: p. 1) [35] pointed to irregularities done by Mobily and the responsibility of management and external auditor Deloitte Saudi Arabia:

It seems that the company reported revenues on contracts that were yet to mature. These are the contracts in which future installments are recognized by the company in full value upfront as revenue. Obviously in accounting this is a big NO-NO as you only report revenues once the service has been delivered not contracted, especially when there are opt-outs in the contracts. You cannot treat Operating leases as Capital leases simply because ownership will shift at the end of a contract. I guess with so many bonuses at stake (CEO reportedly earned on average SAR 30 million every year).

Mobily appointed KPMG as an auditor in 2015 and Mr. Suliman bin Abdulrahman Al Gwaiz became Chairman of the Board who is also Chairman of Bank Saudi Fransi and Governor of the General Organization for Social Insurance (GOSI)!!!!. Mr. Al Gwaiz in addressing stakeholders in Mobily Annual Report (2015: p. 16) states [33]:

Further reorganization of Mobily's corporate governance framework will ensure clearer policies and responsibilities for the future, and better define the rules by which the Company is managed. We have begun the process of instilling a culture of transparency across all departments, and are of the view that this culture should originate at the top. We look forward to playing a key role in a new chapter in the Company's continuing development. 
Mr. Ahmad Farroukh was appointed as CEO for the company in July 2015 and resigned in $9^{\text {th }}$ of January 2017 although he has strong and successful experience in KPMG, Deloitte and was working previously in auditing and financial control but it seems problems in the company are tremendous. On $20^{\text {th }}$ of December 2016, CFO of Mobily announced that the company got two billion SAR from Alinma Bank without any guarantees and company debts are sixteen billions and all of it without any guarantees although the company revenues is decreasing. The new debentures 10-year loan facility from Alinma Bank will help the company's liquidity situation and meant to regain confidence with banks. The company is suffering from high debt ratio as well sharp decline in earnings per share (Figure 4, Figure 5).

On $23^{\text {rd }}$ of December 2016, the management deal between Etisalat United Arab Emirates was not renewed and it was major shareholder. This pulling of Etisalat Holdings from Saudi Arabia will have impact on Mobily in 2017 (Wood, 2017) [36].

\section{Conclusion}

Strengthening corporate governance as well as more restriction to managers will help in regaining confidence of stakeholders. Underneath any corporate accounting and auditing scandals we have greed managers, an auditing office sharing the benefits and loose regulations. Corporate governance is intended to

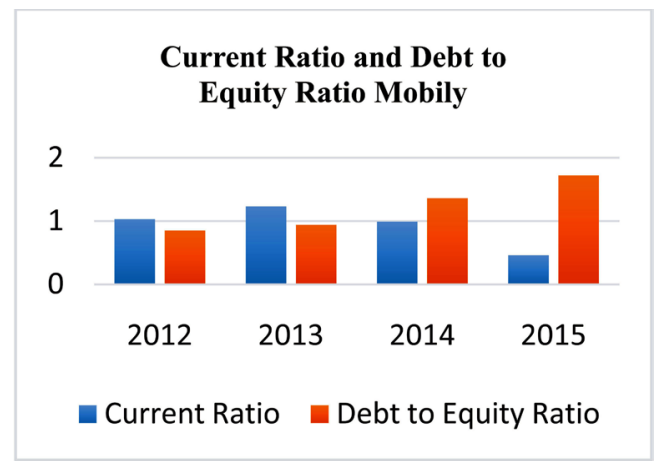

Figure 4. Current and debt to equity ratio.

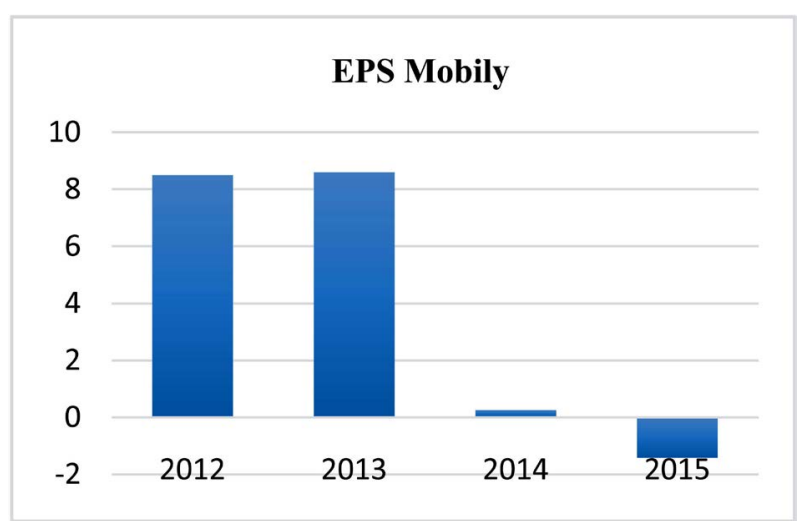

Figure 5. EPS Mobily. 
increase accountability of corporations and to avoid problems before they occur. Chief executive officers and chief financial officers must be responsible and liable for any losses occurred according to false information presented to stakeholders. Delaying of authorities in KSA in taking corrective actions with accused companies and auditing offices will not help markets to regain confidence. Transparency is essential to maintain trust as essential pillar for business success. Auditors who were supposed to act as watchdogs did not bark when they are supposed to do. Auditing companies in Saudi Arabia must be suspended for number of years and jail penalty should be legalized for approving false financial statements. Banks asset evaluation departments should not be involved by any means when banks are underwriting stocks for IPOs. There must be complete overhauling of corporate governance rules in order for presenting true and representative information for the financial performance and position of companies otherwise we will witnessed more Enron's in Saudi Arabia.

\section{References}

[1] Mathisen, K. and Foley, S. (2006) The Role of Ethics in Recent Corporate Scandals. pp.1-8. http://www.g-casa.com/PDF/Mathisen-2007.pdf

[2] Isa, T. (2011) Impacts and Losses Caused By the Fraudulent and Manipulated Financial Information on Economic Decisions. Review of International Comparative Management, 12, 929-939.

[3] Association of Certified Fraud Examiners (2014) Report to the Nations on Occupational Fraud and Abuse. pp. 1-80.

https://www.acfe.com/rttn2016/docs/2016-report-to-the-nations.pdf

[4] Kassem, R. and Higson, A. (2012) The New Fraud Triangle Model. Journal of Emerging Trends in Economics and Management Sciences, 3, 191-195.

[5] Wolfe, D.T. and Hermanson, D.R. (2004) The Fraud Diamond: Considering the Four Elements of Fraud. The CPA Journal, December, 1-5.

[6] Abdullahi, R. and Mansor, N. (2015) Fraud Triangle Theory and Fraud Diamond Theory. Understanding the Convergent and Divergent For Future Research. International Journal of Academic Research in Accounting, Finance and Management Sciences, 5, 38-45.

[7] Todorovic, I. (2013) Impact of Corporate Governance on Performance of Companies. Montenegrin Journal of Economics, 9, 47-53.

[8] Black, B., Jang, H. and Kim, W. (2003) Does Corporate Governance Affect Firm Value? Evidence from Korea.

http://www.haas.berkeley.edu/groups/finance/black.pdf

[9] Haryono, U. and Paminto, A. (2015) Corporate Governance and Firm Value: The Mediating Effect of Financial Performance and Firm Risk. European Journal of Business and Management, 7, 18-24.

[10] Ho, P., Aripin, N. and Greg, T. (2012) Corporate Governance Failure to Influence the Communication of Key Financial Data over Turbulent Times. Journal of Applied Management Accounting Research, 10, 35-52.

[11] Klai, N. and Omri, A. (2011) Corporate Governance and Financial Reporting Quality: The Case of Tunisian Firms. International Business Research, 4, 158-166. 
[12] Firth, M., Fung, P. and Rui, O. (2007) Ownership, Two-Tier Board Structure, and the Informativeness of Earnings: Evidence from China. Journal of Accounting and Public Policy, 26, 463-496. https://doi.org/10.1016/j.jaccpubpol.2007.05.004

[13] Al-Twaijry, A., Brierley, J. and Gwilliam, D. (2002) An Examination of the Role of Audit Committees in the Saudi Arabian Corporate Sector. Corporate Governance, 10, 288-297.

[14] Alzeban, A. (2015) Influence of Audit Committee Industry Expertise on Internal Audit. International Journal of Business and Management, 10, 26-34. https://doi.org/10.5539/ijbm.v10n4p26

[15] Bhasin, M. (2013) Corporate Accounting Fraud: A Case Study of Satyam Computers Limited. Open Journal of Accounting, 2, 26-38.

[16] Alves, G. (2011) The Effect of the Board Structure on Earnings Management: Evidence from Portugal. Journal of Financial Reporting and Accounting, 9, 141-160. https://doi.org/10.1108/19852511111173103

[17] Adkins, T. (2009) Financial Statement Manipulation an Ever-Present Problem for Investors.

http://www.investopedia.com/articles/fundamental-analysis/financial-statement-ma nipulation.asp\#ixzz2HAvPX6PT

[18] Thomas, W. (2002) The Rise and Fall of Enron. Journal of Accountancy, 1-7.

[19] L'Huillier, B. (2014) What Does “Corporate Governance” Actually Mean? Corporate Governance, 14, 300-319. https://doi.org/10.1108/CG-10-2012-0073

[20] Edelman, D. and Nicholson, A. (2011) Arthur Anderson Auditors and Enron: What Happened to Their Texas CPA Licenses? Journal of Finance and Accountancy, 8, 1-9.

[21] Melis, A. (2005) Corporate Governance Failures: To What Extent Is Parmalat a Particularly Italian Case? Corporate Governance, 478-488.

https://doi.org/10.1111/j.1467-8683.2004.00443.x

[22] Roberts, R., Swanson, R. and Dinneen, J. (2004) Spilt Milk: Parmalat and Sarbanes-Oxley Internal Controls Reporting. International Journal of Disclosure and Governance, 1, 215-225. https://doi.org/10.1057/palgrave.jdg.2040026

[23] Duval, J. (2016) Financial Delinquency and the "Big Four" Audit Firms. http://www.globalresearch.ca/financial-delinquency-and-the-big-four-audit-firms/5 549371

[24] Ferrarini, G. and Giudici, P. (2005) Financial Scandals and the Role of Private Enforcement: The Parmalat Case. Law Working Paper No. 40/2005. https://papers.ssrn.com/sol3/papers.cfm?abstract_id=730403

[25] Chikatsu, T. (2015) Toshiba’s True Colours. http://app1.hkicpa.org.hk/APLUS/2015/08/pdf/10_Toshiba.pdf

[26] Khondaker, R. and Marc, B. (2016) Accounting Irregularities at Toshiba: An Inquiry into the Nature and Causes of the Problem and Its Impact on Corporate Governance in Japan. Global Advanced Research Journal of Management and Business Studies, 5, 88-101.

[27] Baydoun, N., Maguire, W., Ryan, N. and Willet, R. (2012) Corporate Governance in Five Arabian Gulf Countries. Managerial Auditing Journal, 28, 7-22. https://doi.org/10.1108/02686901311282470

[28] MMG (2008) Mohammad Al Mojil Group: Prospects. https://cma.org.sa/en/Market/Prospectuses/Documents/MMG_English.pdf 
[29] Saudi Stock Exchange (2013) Awareness Material \& Frequently Asked Questions. https://www.tadawul.com.sa/Resources/CompaniesWithAccumLoss_Procedure_en. pdf

[30] Capital Market Authority (2014).

http://twitmails3.s3-website-eu-west-1.amazonaws.com/users/233429974/361/attac hment/\%D8\%AA\%D8\%B9\%D9\%85\%D9\%8A\%D9\%85\%20\%D8\%A7\%D9\%8A\%D9 \%82\%D8\%A7\%D9\%81\%20\%D9\%85\%D9\%83\%D8\%AA\%D8\%A8\%20\%D8\%AF\%D 9\%8A\%D9\%84\%D9\%88\%D9\%8A\%D8\%AA.pdf

[31] Jones, R. and Patrick, M. (2015) HSBC Unit in the Cross Hairs of Saudi Regulator. Wall Street Journal, July 162015.

[32] Everington, J. (2016) Board of Troubled Saudi Contractor Mohammed Al Mojil Group Resigns. The National Business.

http://www.thenational.ae/business/economy/board-of-troubled-saudi-contractormohammed-al-mojil-group-resigns

[33] Annual Report Mobily (2015).

http://www.mobily.com.sa/portalu/wps/wcm/connect/ba510477-92fe-45cf-994e-bd 32712fd47e/Annual+Report-En-2015_Final.PDF?MOD=AJPERES\&CACHEID=ba5 10477-92fe-45cf-994e-bd32712fd47e

[34] Martin, M. and Almashabi, D. (2015) Mobily Chairman's Company Sold Bulk of Stake before He Resigned.

https://www.bloomberg.com/news/articles/2015-03-04/mobily-chairman-s-compan y-sold-bulk-of-stake-before-he-resigned

[35] Watfa, R. (2015) How Significant Were Mobily's Accounting Errors: Credit Risk. http://www.credit-risk-store.com/how-significant-were-mobilys-accounting-errorscredit-risk/

[36] Wood, N. (2017) Mobily Names New CEO.

http://www.totaltele.com/495857/Mobily-names-new-CEO 